\title{
PENGARUH PENAMBAHAN TEPUNG DAUN KELOR (Moringa oleifera) TERHADAP KARAKTERISTIK ORGANOLEPTIK DAN KIMIA BISKUIT MOCAF (Modified Cassava Flour)
}

\author{
The Effectof the Addition of Moringa (Moringa oleifera) Leaf Flour on the Organolpectic and \\ Chemical Properties of MOCAF (Modified Cassava Flour) Biscuits
}

\section{Gelora Helena Augustyn*, Helen Cynthia Dewi Tuhumury, Matheos Dahoklory}

\author{
Jurusan Teknologi Hasil Pertanian, Fakultas Pertanian, Universitas Pattimura \\ Jl. Ir. M. Putuhena Kampus Poka, Ambon 97233 \\ *Penulis Korespondensi: hgelora@yahoo.com
}

\begin{abstract}
The purpose of the research was to analyse the effect of Moringa leaf flour on the organoleptic and chemical properties of mocaf biscuit. A completely randomized experimental design was applied with single factor having a levels of flour adition, P1 (0:100), P2 (3:100), P3 (6:100) dan P4 (9:100). Result showed that nutritional content of moringa leaf flour on moisture, protein, vitamin $\mathrm{C}$ and carbohydrate contents were 9.57\%, 26.02\%, $1.2 \%$ and 51.91\% respectively. Mocaf biscuit made of P2 (3:100) was found to be the best product with the moisture, ash, fat, protein, vitamin $\mathrm{C}$, and carbohydrate content of $2.74 \%, 1.41 \%, 2.20 \%$, $11.15 \%, 10.12 \%, 0.25 \%$ and $72.12 \%$ subsequently. The biscuit made with this $\mathrm{P} 2$ result in organoleptic properties that were mostly prefered by panelists on colour (3.20), aroma (3.22), texture (3.32), taste (3.20) and overall (3.41).
\end{abstract}

Keywords: biscuit, MOCAF, moringa leaf flour

\begin{abstract}
ABSTRAK
Penelitian bertujuan untuk menganalisa pengaruh penambahan tepung daun kelor terhadap karakteristik organoleptic dan kimia biskuit mocaf. Penelitian ini menggunakan Rancangan Acak Lengkap (RAL) Faktor Tunggal dengan 1 taraf perlakuan penambahan tepung daun kelor $(\mathrm{P})$ dan tepung mocaf dengan tiga kali ulangan. Taraf perlakuan dalam penelitian yaitu: P1 (0:100), P2 (3:100), P3 (6:100), dan P4(9:100). Hasil penelitian menghasilkan kandungan gizi tepung daun kelor yaitu: 9,57\% kadar air, 7,85\% kadar abu, 4,03\% kadar serat, 2,52\% kadar lemak, 26,02\% kadar protein, 1,92\% kadar vitamin C dan 51,91\% kadar karbohidrat, sedangkan biskuit mocaf dengan perlakuan P2 (3:100) memiliki 2,74\% kadar air, 1,41\% kadar abu, 2,20\% kadar serat, 11,52\% kadar lemak, 10,12\% kadar protein, 0,25\% kadar vitamin C, dan 72,38\%. Hasil uji organoleptik, panelis menyukai biskuit mocaf untuk tingkat kesukaan terhadap warna 3,20 (suka), aroma 3,22 (suka), tekstur 3,32 (suka), rasa 3,20 (suka), dan overall 3,41 (suka).
\end{abstract}

Kata kunci: biskuit, MOCAF, tepung daun kelor

\section{PENDAHULUAN}

Ubi kayu merupakan salah satu sumber karbohidrat lokal Indonesia yang menduduki urutan ketiga terbesar setelah padi dan jagung. Pemanfaatan ubi kayu sebagian besar hanya sebagai produk setengah jadi berupa pati, tepung ubi kayu, gaplek, dan chips. Usaha difersivikasi pangan yang lain adalah dengan mengolahnya menjadi modified cassava flour (MOCAF) (Ginting, 2002).

MOCAF merupakan produk tepung dari ubi kayu yang diperas menggunakan prinsip memodifikasi sel ubi kayu secara fermentasi (Subagio, 2008). Keberadaan tepung MOCAF sangat penting karena merupakan alternatif pengganti tepung terigu. 
Kandungan nutrisi yang mendasar pada mocaf adalah karbohidrat dan sedikit protein oleh karena itu dalam pembuatan biskuit diperlukan formulasi yang baik untuk menjaga mutu produk. Salah satu bahan makanan yang dapat ditambahkan pada biskuit yaitu tepung daun kelor. Selama ini daun kelor hanya dijadikan sayur untuk hidangan pendamping nasi dan masih dikonsumsi oleh beberapa daerah saja di Indonesia.

Kelor (Moringa oleifera) adalah tanaman yang banyak dijumpai didaerah tropis dan sudah dikenal luas di Indonesia, khususnya di daerah pedesaan, tetapi belum dimanfaatkan secara maksimal. Kelor dikenal sebagai tanaman ajaib "moringa the micacle tree" karena sifat multifungsi bagi manusia. Daun kelor sangat berguna bagi manusia baik sebagai pangan bergizi maupun sebagai obat herbal (fitofarmaka) (Simbolan et al., 2007; Hsu et al., 2006; Oduro et al., 2008). Kelor memiliki kandungan nutrisi yang cukup kompleks, senyawa organik yang terkandung dalam $100 \mathrm{~g}$ tepung daun kelor diantaranya adalah tinggi kandungan protein $6,8 \mathrm{~g}$, ß-karoten $6,78 \mathrm{mg}$, mineral terutama zat bezi $7 \mathrm{mg}$, fosfor $70 \mathrm{mg}$, dan vitamin C $220 \mathrm{mg}$ (Fuglie, 2002).

Salah satu bentuk olahan produk pangan yang diminati anak-anak hingga orang dewasa mulai dari masyarakat ekonomi bawah sampai atas adalah biskuit. Biskuit adalah sejenis makanan yang terbuat dari tepung terigu dengan penambahan bahan makanan lain, dengan melalui proses pemanasan dan pencetakan (BSN, 1992). Tepung kelor kaya akan protein, mineral dan vitamin. Kelebihan dari penambahan tepung kelor ini bisa meningkatkan kualitas dari biskuit, karena kelor memiliki kandungan mikro yang tinggi (Aminah et al., 2015). Dalam proses pembuatan produk yang memiliki kandungan gizi yang rendah, penambahan tepung daun kelor dapat meningkatkan nilai gizi dari produk tersebut. Pemanfaatan tepung daun kelor dan MOCAF sebagai baku biskuit diharapkan dapat mengurangi ketergantungan penggunaan tepung terigu dan juga dapat meningkatkan nilai ekonomis tepung kelor dan MOCAF.

Hasil penelitian penggunaan tepung daun kelor dalam penelitian terdahulu barulah sebatas subtitusi dalam pembuatan biskuit, diantaranya oleh Kholis dan Hadi (2010) dan Suarti et al. (2015), dimana setiap perlakuan penambahan ekstrak maupun tepung daun kelor memberikan pengaruh nyata terhadap kandungan karbohidrat, protein, mineral, dan organoleptik biskuit.

\section{METODE PENELITIAN}

\section{Bahan}

Bahan yang digunakan dalam pembuatan biskuit adalah tepung MOCAF, tepung kelor, garam, gula pasir, mentega, telur, susu bubuk dan bahan pengembang. Bahan yang diperlukan untuk analisis kimia adalah akuades, natrium hidroksida $(\mathrm{NaOH})$, indikator campuran (bromcressol green dan methil), larutan asam klorida, larutan asam borat $\left(\mathrm{H}_{3} \mathrm{BO}_{3}\right)$, larutan asam sulfat $\left(\mathrm{H}_{2} \mathrm{SO}_{4}\right)$, indikator fenoltalin (pp), larutan luff, larutan kalium iodida, dan larutan tiosulfat.

\section{Pembuatan Tepung Kelor}

Proses pembuatan tepung kelor diawali dengan pemilihan bahan baku yang baik untuk mendapatkan produk yang bermutu. Daun kelor yang digunakan adalah daun kelor segar. Setelah mendapatkan daun kelor segar, kemudian dilakukan sortasi dan pencucian. Selanjutnya daun kelor yang telah dicuci ditiriskan untuk mengurangi jumlah air pada daun kelor, kemudian dikeringkan menggunakan pengeringan matahari selama 6 jam pada suhu $\pm 30^{\circ} \mathrm{C}$. Setelah kering dilakukan penggilingan dan pengayakan dengan ayakan 80 mesh sehingga diperoleh hasil tepung daun kelor.

\section{Pembuatan Biskuit}

Pembuatan biskuit diawali dengan pencampuran bahan-bahan antara lain gula $50 \%$ $\mathrm{b} / \mathrm{b}$, margarin $50 \% \mathrm{~b} / \mathrm{b}$, kuning telur $14 \% \mathrm{~b} / \mathrm{b}$, dilanjutkan dengan proses pengocokan sampai menyatu, kemudian tambahkan tepung daun kelor dan MOCAF dengan perbandingan sesuai perlakuan yaitu $0 \%: 100 \%, 3 \%: 100 \%, 6 \%: 100 \%$, 9\%:100\% serta susu bubuk $27 \% \mathrm{~b} / \mathrm{b}$, garam $1,5 \%$ $\mathrm{b} / \mathrm{b}$ secara bertahap kemudian diaduk dengan mixer selama kurang lebih 30 menit hingga adonan tercampur merata. Adonan yang diperoleh kemudian dicetak dan dipanggang dalam oven pada suhu $160^{\circ} \mathrm{C}$ selama 20 menit.

\section{Pengamatan}

Pengujian organoleptik dilakukan terhadap warna, tekstur, rasa dan tingkat kesukaan. Sedangkan analisa kimia meliputi kadar air dengan metode pengeringan (AOAC, 2007), kadar abu dengan metode pengabuan langsung (AOAC, 
2007), kadar protein dengan Metode Kjehdahl (AOAC, 2007), kadar serat, kadar lemak dengan Metode Soxhlet (AOAC, 2007), dan karbohidrat dengan Metode by difference

\section{Analisis Data}

Data hasil penelitian diuji secara statistik dengan menggunakan analisis keragaman sesuai dengan rancangan yang digunakan. Beda antara rataan perlakuan di uji dengan uji beda nyata terkecil pada taraf 5\% untuk tiap peubah dengan pengaruh perlakuan nyata atau sangat nyata.

\section{HASIL DAN PEMBAHASAN}

\section{Analisa Tepung Daun Kelor}

Tujuan dilakukan analisa awal pada tepung daun kelor ini adalah untuk membandingkan hasil analisa kimia awal dengan hasil analisa kimia produk akhir, sehingga dapat menentukan pengaruh penambahan tepung daun kelor terhadap mutu biskuit MOCAF.

Tabel 1. Ringkasan hasil analisis tepung daun kelor

\begin{tabular}{lc}
\hline \multicolumn{1}{c}{ Parameter } & Tepung Daun Kelor (\%) \\
\hline Kadar Air & 9,57 \\
Kadar Abu & 7,85 \\
Kadar Karbohidrat & 51,91 \\
Kadar Serat & 4,03 \\
Kadar Lemak & 2,52 \\
Kadar Protein & 26,02 \\
Kadar Vitamin C & 1,92 \\
\hline
\end{tabular}

Berdasarkan hasil pada Tabel 1, kadar air tepung daun kelor hasil analisis (9,57\%) lebih tinggi dibandingkan penelitian sebelumnya yaitu kadar air tepung daun kelor 7,5\% (Fuglie, 2002). Kadar air yang lebih rendah ini dapat disebabkan bahan baku yang digunakan berbeda dengan penelitian yang sebelumnya, selain itu metode pengeringan matahari yang dipakai untuk membuat tepung juga akan mempengaruhi mutu tepung yang dihasilkan (Indrasti, 2004).

Berdasarkan Tabel 1, Kadar abu tepung daun kelor yang diperoleh sebesar 7,85\% lebih rendah dibandingkan hasil penelitian sebelumnya $8,57 \%$ (Pangaribuan, 2013). Menurut De Man (1997) kadar abu dalam tumbuhan dipengaruhi kelimpahan mineral dari lingkungan atau tanah tempat tanaman tersebut tumbuh.
Kadar lemak pada tepung daun kelor adalah sebesar 2,52\%. Hasil ini berbeda dengan penelitian yang dilakukan oleh Fuglie (2002) yang mendapatkan hasil 1,2\%. Perbedaan ini bisa disebabkan oleh perbedaan varietas, iklim, kesuburan tanah dan umur panen dari daun kelor yang digunakan untuk membuat tepung.

Hasil analisis kadar protein tepung daun kelor adalah sebesar 26,02\%. Dari hasil ini terlihat bahwa kadar protein tepung daun kelor sangat tinggi. Hal ini menunjukkan tepung daun kelor dapat digunakan sebagai bahan tambahan dalam pembuatan biskuit untuk menghasilkan produk biskuit dengan kandungan protein yang tinggi.

Kadar vitamin $\mathrm{C}$ pada serbuk daun kelor adalah sebesar 1,95\%. Dari hasil ini terlihat bahwa kadar vitamin $\mathrm{C}$ tepung daun kelor sangat tinggi dan memungkinkan untuk digunakan sebagai bahan baku untuk menghasilkan produk yang mengandung vitamin $\mathrm{C}$ yang tinggi.

Serat sangat penting dalam penilaian kualitas bahan pangan karena angka ini merupakan angka indeks dan menentukan nilai gizi bahan makanan tersebut (Sudarmadji et al., 1997). Berdasarkan hasil analisis didapat kadar serat pada tepung kelor adalah sebesar 4,3\%.

Kadar karbohidrat pada tepung daun kelor adalah $51,91 \%$. Kandungan karbohidrat yang tinggi ini memungkinkan tepung daun kelor dapat diolah menjadi berbagai macam makanan.

\section{Pengujian Organoleptik}

Pengujian organoleptik dilakukan untuk mengetahui tingkat kesukaan panelis terhadap biskuit mocaf yang meliputi warna, rasa, aroma, tekstur dan overall (Tabel 2).

\section{Warna}

Tabel 2 menunjukkan bahwa dari 30 panelis yang melakukan pengujian ternyata penilaian tertinggi terhadap warna dimiliki oleh biskuit perlakuan (A0) sebesar 3,62 (mendekati sangat suka) dan nilai terendah dimiliki oleh biskuit perlakuan (A3) sebesar 2,50 (agak suka). Dapat dilihat pula bahwa perlakuan (A0) berbeda nyata dengan perlakuan (A1), (A2), dan (A3), sedangkan perlakuan (A1) tidak berbeda nyata dengan perlakuan (A2) tetapi berbeda nyata dengan perlakuan (A3). 
Tabel 2. Ringkasan hasil uji hedonik biskuit

\begin{tabular}{cccccc}
\hline $\begin{array}{c}\text { Perla } \\
\text { kuan }\end{array}$ & Warna & Aroma & Tekstur & Rasa & Overall \\
\hline $0 \%$ & $3,62 \mathrm{a}$ & $3,23 \mathrm{a}$ & $3,22 \mathrm{a}$ & $3,33 \mathrm{a}$ & $3,36 \mathrm{a}$ \\
$3 \%$ & $3,20 \mathrm{~b}$ & $3,22 \mathrm{a}$ & $3,32 \mathrm{a}$ & $3,67 \mathrm{a}$ & $3,41 \mathrm{a}$ \\
$6 \%$ & $2,86 \mathrm{bc}$ & $2,98 \mathrm{a}$ & $3,30 \mathrm{a}$ & $3,35 \mathrm{a}$ & $3,04 \mathrm{a}$ \\
$9 \%$ & $2,50 \mathrm{c}$ & $2,48 \mathrm{~b}$ & $2,60 \mathrm{~b}$ & $2,64 \mathrm{~b}$ & $2,51 \mathrm{~b}$ \\
\hline
\end{tabular}

Keterangan: Notasi yang sama pada kolom yang sama menunjukkan tidak ada perbedaan yang nyata pada uji $\operatorname{BNJ}(\alpha=0,01)$

Panelis lebih menyukai perlakuan (A0) karena panelis telah terbiasa dengan biskuit yang berwarna coklat, jika dibandingkan dengan perlakuan (A1), (A2), dan (A3) yang berwarna agak hijau sampai kehijauan, diduga disebabkan karena semakin banyak tepung daun kelor yang ditambahkan menyebabkan penurunan tingkat penerimaan panelis terhadap warna biskuit yang dihasilkan.

\section{Aroma}

Tabel 2 menunjukkan bahwa dari 30 panelis yang melakukan pengujian ternyata penilaian tertinggi terhadap aroma dimiliki oleh biskuit perlakuan (A0) sebesar 3,23 (suka) dan nilai terendah dimiliki oleh biskuit perlakuan (A3) sebesar 2,48 (agak suka). Panelis lebih suka aroma biskuit yang dibuat dengan perlakuan (A0) tanpa penambahan tepung kelor, hal ini diduga disebabkan karena bau mentah pada tepung daun kelor telah dominan dalam produk biskuit, selain itu juga disebabkan karena belum terbiasanya panelis dengan aroma tepung daun kelor. Dapat dilihat pula bahwa perlakuan (A0) tidak berbeda nyata dengan perlakuan (A1), (A2), namun berbeda nyata dengan perlakuan (A3), sedangkan perlakuan (A1) tidak berbeda nyata dengan perlakuan (A2) tetapi berbeda nyata dengan perlakuan (A3) sedangkan perlakuan (A2) berbeda nyata dengan perlakuan (A3).

Berdasarkan hasil penelitian, dapat dilihat bahwa semakin tinggi penambahan tepung daun kelor maka hasil organoleptik terhadap aroma semakin menurun. Menurunnya tingkat penerimaan terhadap aroma biskuit, disebabkan karena penambahan tepung daun kelor telah menutupi bahan yang digunakan, karena bau langu pada tepung daun kelor

\section{Tekstur}

Tabel 2 menunjukkan bahwa dari 30 panelis yang melakukan pengujian ternyata penialain tertinggi terhadap tekstur dimiliki oleh biskuit perlakuan (A1) sebesar 3,32 (suka) dan nilai terendah dimiliki oleh biskuit perlakuan (A3) ebesar 2,6 (agak suka). Panelis lebih suka tekstur biskuit yang dibuat dengan perlakuan (A1) penambahan tepun kelor 3\%, hal ini diduga disebabkan karena penambahan tepung daun kelor dapat menaikan viskositas bahan sehingga menghasilkan tekstur yang baik dan disukai oleh panelis. Dapat dilihat pula bahwa perlakuan (A0) tidak berbeda nyata dengan perlakuan (A1), dan (A2) namun berbeda nyata dengan perlakuan (A3), perlakuan (A1), dan (A2) namun berbeda nyata dengan perlakuan (A3), perlakuan (A1) tidak berbeda nyata dengan perlakuan (A2) tetapi berbeda nyata dengan perlakuan (A3).

Berdasarkan Tabel 2 dapat dilihat bahwa respons panelis terhadap tekstur biskuit semakin menurun dengan adanya penambahan tepung daun kelor, kecederungannya semakin tinggi penambahan tepung daun kelor, biskuit yang dihasilkan akan semakin keras. Hal ini diduga disebabkan karena perbedaan kandungan tepung pada tiap perlakuan menentukan perolehan kadar air biskuit, sehingga mempengaruhi tekstur yang dihasilkan sebab kadar air berpengaruh terhadap kenampakan, tekstur dan cita rasa dari suatu makanan.

\section{Rasa}

Tabel 2 menunjukkan bahwa dari 30 panelis yang melakukan pengujian ternyata penilaian tertinggi terhadap rasa dimiliki oleh biskuit perlakuan (A1) sebesar 3,76 (mendekati sangat suka) dan nilai terendah dimiliki oleh biskuit perlakuan (A3) sebesar 2,64 (agak suka). Panelis lebih suka rasa biskuit yang dibuat dengan perlakuan (A1) penambahan tepung kelor 3\%, hal ini diduga disebabkan karena pada penambahan konsentrasi $3 \%$ rasa biskuit belum didominasi oleh aroma dan rasa tepung daun kelor. Dapat diliha pula bahwa perlakuan (A0) tidak berbeda nyata dengan perlakuan (A1), dan (A2), namun berbeda nyata dengan perlakuan (A3), perlakuan (A1) tidak berbeda nyata dengan perlakuan (A2) tetapi berbeda nyata dengan perlakuan (A3) sedangkan perlakuan (A2) berbeda nyata dengan perlakuan (A3). 
Tabel 2 menunjukkan bahwa penilaian panelis terhadap rasa semakin menurun dengan semakin bertambahnya penambahan tepung daun kelor, hal ini diduga karena semakin tinggi penambahan tepung daun kelor akan menambah cita rasa khas daun kelor yang kurang disukai oleh konsumen

\section{Overall}

Tabel 2 menunjukkan bahwa dari 30 panelis yang melakukan pengujian ternyata penilaian tertinggi terhadap overall dimiliki oleh biskuit perlakuan (A1) sebesar 3,41 (suka) dan nilai terendah dimiliki oleh biskuit perlakuan (A3) sebesar 2,51 (agak suka).

Parameter keseluruhan (overall) digunakan dalam uji hedonic untuk mengukur tingkat kesukaan panelis terhadap keseluruhan atribut yang ada pada produk. Formula A1 memiliki daya terima keseluruhan yang lebih tinggi dari ketiga formula lainnya.

Pemilihan formulasi terbaik pada biskuit daun kelor yaitu perlakuan (A1) yakni 3\% tepung daun kelor $+100 \%$ tepung mocaf. Kandungan gizi pada biskuit diuji dengan melakukan analisi proksimat meliputi kadar air, kadar abu, kadar protein, lemak, vitamin $\mathrm{C}$, serat dan karbohidrat

Tabel 3. Ringkasa Hasil Analisis Kimia Biskuit

\begin{tabular}{cc}
\hline Parameter & Hasil Uji \\
\hline Kadar Air & $2,74 \%$ \\
Kadar Abu & $1,41 \%$ \\
Kadar Karbohidrat & $72,12 \%$ \\
Kadar lemak & $11,15 \%$ \\
Kadar protein & $10,12 \%$ \\
Kadar vitamin C & $0,25 \%$ \\
Kadar serat & $2,20 \%$ \\
\hline
\end{tabular}

\section{Analisis Kimia Biskuit}

Tahapan selanjutnya dalam penelitian ini adalah dari 4 taraf perlakuan biskuit mocaf hanya dipilih 1 perlakuan yang terbaik secara organoleptic untuk dianalisis secara kimia yaitu perlakuan (A1) yakni penambahan tepung daun kelor $3 \%$. Parameter yang diamati pada penelitian ini adalah kadar air, kadar abu, kadar karbohidrat, kadar lemak, kadar protein, kadar vitamin $\mathrm{C}$ dan kadar serat (Tabel 3).

\section{Kadar Air}

Berdasarkan hasil pada Tabel 3, kadar air biskuit yang dihasilkan 2,74\%. Kadar air biskuit ini jika dibandingkan dengan kadar air awal bahan yaitu tepung daun kelor $9,57 \%$ maka dapat dikatakan bahwa kadar air pada hasil akhir produk mengalami penurunan.

Hal ini diduga disebabkan karena pada proses pemanasan dan pemangganagan terjadi reaksi antara senyawa-senyawa yang terkandung disalam komposisi biskuit sehingga uap air dalam baha mengalami penguapan. Suarti et al. (2015) melaporkan bahwa selama waktu pemanasan kemungkinan bahan untuk kehilangan kadar airnya semakin besar. Sedangkan kadar air biskuit jika dibandingkan dengan syarat mutu biskuit berdasarkan SNI 01-2973-1992 (BSN, 1992) dimana kadar air maksimum yang terdapat pada biskuit adalah 5\% (bb) maka kadar air biskuit yang dihasilkan masih berada dibawah persyaratan SNI, sehingga dapat dikatakan bahwa kadar air biskuit dengan penambahan tepung daun kelor memenuhi persyaratan mutu biskuit berdasarkan SNI.

\section{Kadar Abu}

Berdasarkan hasil pada Tabel 3, kadar abu biskuit yang dihasilkan $1,41 \%$. Kadar abu biskuit ini jika dibandingkan dengan kadar abu awal bahan tepung daun kelor $7,85 \%$ maka dapat dikatakan bahwa kadar abu pada hasil akhir produk mengalami penurunan. Penurunan kadar abu ini disebabkan karena kadar air pada bahan baku yang terbilang cukup tinggi sehingga dapat melarutkan kandungan abu. Sedangkan kadar abu biskuit jika dibandingkan dengan syarat mutu biskuit berdasarkan SNI 01-2973-1992 (BSN, 1992) dimana kadar abu maksimum yang terdapat pada biskuit adalah $1,5 \%$ (bb) maka kadar biskuit yang dihasilkan masih berada dibawah persyaratan SNI, sehingga dapat dikatakan bahwa kadar abu biskuit dengan penambahan tepung daun kelor memenuhi persyaratan mutu biskuit berdasarkan SNI.

\section{Kadar Lemak}

Berdasarkan hasil pada Tabel 3, kadar lemak yang dihasilkan $11,15 \%$. Kadar abu biskuit ini jika dobandingkan dengan kadar abu awal bahan yaitu tepung kelor 2,52\% maka dapat dikatakan bahwa kadar lemak pada hasil akhir produk mengalami kenaikan kadar lemak ini disebabkan karena 
penambahan bahan-bahan lain yang kaya akan lemak seperti margarin dan telur. Sedangkan kadar lemak biskuit jika dibandingkan dengan syarat mutu biskuit berdasarkan SNI 01-2973-1992 (BSN, 1992) dimana kadar lemak minimal yang terdapat pada biskuit adalah 9,5\% (bb) maka kadar lemak biskuit yang dihasilkan lebih besar dari persyaratan SNI, sehingga dapat dikatakan bahwa kadar lemak biskuit dengan penambahan tepung daun kelor memenuhi persyaratan mutu biskuit berdasarkan SNI.

\section{Kadar Karbohidrat}

Berdasarkan hasil pada Tabel 3, menunjukkan bahwa kadar karbohidrat biskuit menggunakan formulasi tepung daun kelor adalah $72,12 \%$ (bb). Dapat dikatakan bahwa penambahan tepung daun kelor dapat meningkatkan kadar karbohidrat pada produk biskuit, hal ini diduga karena pada proses pencampuran bahan terjadi reaksi antara senyawa-senyawa sehingga menyebabkan kelarutan abu, selain itu pemanasan dan pemanggangan terjadi reaksi antar senyawasemyawa yang menyebabkan terjadinya denaturasi protein dan penguapan air (Buckle, 2008). Jika dibandingkan dengan persyaratan minimum kadar karbohidrat biskuit yang tercantum pada SNI (70\%), kadar karbohidrat biskuit dengan subsitusi tepung daun kelor sudah mencapai SNI. Hal ini dikarenakan terjadi penggantian tepung terigu dengan mocaf yang menjadi sumber utama karbohidrat pada biskuit dengan tepung daun kelor yang tinggi protein dan rendah karbohidrat.

\section{Kadar Protein}

Kadar protein biskuit yang dihasilkan pada penelitian ini adalah $10,12 \%$ jika dibandingkan kadar protein awal tepung daun kelor mengalami penurunan, hal ini disebabkan karena pada proses pemanggangan protein mengalami denaturasi karena tidak tahan terhadap panas. Niali tersebut telah memenuhi standar menurut SNI No. 01-29731992 (BSN, 1992) yaitu minimal 9\%. Hal ini diduga disebabkan karena tepung daun kelor mempunyai kandungan protein yang tinggi, selain itu penggunaan telur juga dapat meningkatkan kandungan protein biskuit. Umumnya, telur untuk melembutkan struktur biskuit. Penggunaan telur yang lebih banyak dapat meningkatkan kadar protein karena telur adalah sumber protein yang baik (Almatsier, 2010).

\section{Kadar Vitamin C}

Hasil pengukuran vitamin $\mathrm{C}$ biskuit mocaf dengan penambahan tepung daun kelor $2,80 \mathrm{mg} / \mathrm{bb}$. Kandungan vitamin $\mathrm{C}$ biskuit mocaf ini jika dibandingkan dengan SNI biskuit telah sesuai (lebih besar) dari SNI biskuit akan tetapi jika dibandingkan hasil analisa awal tepung daun kelor dapat dikatakan bahwa vitamin $\mathrm{C}$ mengalami penurunan. Hal ini diduga disebabkan karena vitamin $\mathrm{C}$ mengalami kerusakan selama berlangsungnya proses pemanggangan dan gal ini menyebabkan hasilnya turun, sepertiyang dikemukakan oleh Kumulaningsih (2006) bahwa vitamin $\mathrm{C}$ bersifat tidak stabil bila terkena cahaya dan pada suhu tinggi mudah mengalami kerusakan. Begitu juga dengan pemasan yang terjadi pada proses pengolahan biskuit dapat menurunkan kandungan vitamin $\mathrm{C}$, seperti yang dikemukakan oleh Apandi (1984) bahwa proses pengolahan panas dapat mengakibatkan penurunan kandungan vitamin $\mathrm{C}$. vitamin $\mathrm{C}$ yang tinggi pada biskuit ini diduga berasal dari tepung daun kelor.

\section{Kadar Serat}

Berdasarkan penelitian, diperoleh kadar serat adalah 2,20\%. Kandungan serat tersebut jika dibandingkan dengan SNI hasilnya lebih tinggi dari standar karena kadar serat biskuit menurut SNI adalah maksimal $0,5 \%$. Kandungan serta yang cukup tinggi pada biskuit diperoleh dari penambahan tepung daun kelor pada biskuit selain penambahan serbuk daun kelor yang paling berpengaruh adalah kasar serat tepung mocaf itu sendiri. Semakin besar jumlah bahan yang digunakan, kadar sertanya semakin besar.

\section{KESIMPULAN}

Perlakuan A1 dengan penambahan tepung daun kelor 3\% menghasilkan biskuit dengan karakteristik organoleptic yang baik yaitu : warna dengan nilai $(3,20)$ suka, aroma dengan nilai $(3,22)$ suka, tekstur dengan nilai $(3,32)$ suka, rasa dengan nilai $(3,67)$ suka, dan kesukaan overall dengan nilai $(3,41)$ suka, serta perlakuan A1 dengan penambahan tepung daun kelor 3\% menghasilkan biskuit dengan karakteristik kimia yang baik yaitu: kadar air 2,74\%, kadar abu 1,41\%, kadar protein $10,12 \%$, kadar lemak 11,15\%, kadar serat 2,20\%, 
kadar karbohidrat $72,12 \%$. Serta penambahan tepung daun kelor dalam pembuatan biskuit mocaf dapat meningkatkan kandunga gizi (kadar karbohidrat, lemak, protein, vitamin $\mathrm{C}$, dan serat) dari produk biskuit mocaf.

\section{DAFTAR PUSTAKA}

Almatsier, S. 2010. Prinsip Dasar ilmu Gizi. Gramedia Pustaka Utama. Jakarta.

Aminah, S., T. Ramdhan, dan M. Yanis. 2015. Kandungan nutrisi dan sifat fungsional tanaman kelor (Moringa oleifera). Buletin Pertanian Perkotaan 5: 35-44.

AOAC. 2007. Official Methods of Analysis Association of Official Anaylitical Chemist. Inc. Arlington Virginia.

Apandi, M. 1984. Teknologi Buah dan Sayur. Penerbit Alumni. Bandung.

Badan Standarisasi Nasional (BSN). 1992. SNI No 01-28731992 tentang Biskuit. BSN. Jakarta.

Buckle, K.A. 2008. Ilmu Pangan. UI-Press. Jakarta.

De Man. 1997. Kimia Makanan. Penerbit ITB. Bandung.

Fuglie, L.J. 2002. The Miracle Tree Moringa oleifera: Natural Nutrition for the Tropic Church World Service. Dakar. Senegal.

Ginting, E. 2002. Teknologi penanganan pascapanen dan pengolahan ubikayu menjadi produk-antara untuk mendukung agroindustri. Buletin Palawija 4: 67-83.

Hsu, R., S. Midcap, M. Arbainsyah, and L. de Witte. 2006. Moringa Oleifera; Medicinal and Socio-Economic Uses. Internasional Course on Economic Botany. National Herbarium Leiden, the Netherlands.
Indrasti, D. 2004. Pemanfaatan Tepung Talas Belitung (Xanthosoma sagittifolium) dalam Pembuatan Cookies. [Skripsi]. Fakultas Teknologi Pertanian IPB. Bogor

Kholis, N. dan F. Hadi. 2010. Pengujian bioassay biskuit balita yang disuplementasi konsentrat protein daun kelor (Moringa oleifera) pada model tikus malnutrisi. Jurnal Teknologi Pertanian 11: 144-151.

Kumulaningsih, S. 2006. Antioksidan Alami Penangkal Radikal Bebas, Sumber, Manfaat, Cara Penyediaan dan Pengolahan. Trubus Agrisarana. Surabaya.

Oduro, I., W.O. Ellis, and D. Owusu. 2008. Nutritional potential of two leafy vegetables: Moringa oleifera and Ipomoea batatas leaves. Scientific Research and Essay 3: 057060.

Pangaribuan, A.D. 2013. Substitusi Tepung Talas Belitung Pada Pembuatan Biskuit Daun Kelor (Moringa oleifera Lamk). Skripsi. Fakultas Teknobiologi, Universitas Atma Jaya. Yogyakarta.

Subagio. 2008. Pengembangan Tepung MOCAF. Salemba. Jakarta.

Simbolan, J.M., M. Simbolan, and N. Katharina. 2007. Cegah Malnutrisi dengan Kelor. Kanisius. Yogyakarta.

Suarti, B., E. Ardyanto, and M.D. Masyhura. 2015. Penambahan tepung daun kelor dan lama pemanggangan terhadap mutu biskuit dari MOCAF (Modified Cassava Flour). Agrium 19: 238-248.

Sudarmadji, S., B. Haryono, dan Suhardi. 1997. Prosedur Analisa untuk Bahan Makanan dan Pertanian. Liberty. Yogyakarta. 